\title{
ARTE E POLÍTICA: O QUADRO NORMATIVO E A SUA REVERSÃO
}

\author{
Pedro Dolabela Chagas* \\ pedrodolabela@terra.com.br
}

\begin{abstract}
RESUMO $O$ presente ensaio analisa a relação entre arte e política a partir da sua autonomia recíproca, definida como um pressuposto epistemológico para o estudo daquela relação. Analisaremos como as especificidades ontológicas da arte (nos planos da recepção, da produção e do seu entrelaçamento entre semântica e sensorialidade) podem propiciar acontecimentos de caráter político, e também como tais especificidades podem se conciliar com a atividade crítica ou judicativa de vocação política, de maneira que elas sejam respeitadas, e não agredidas. Conforme argumentaremos, uma filosofia que bem se presta a esta função é a de Deleuze e Guattari. Porém, para que a sua importância fique clara, este ensaio será quase integralmente dedicado a expor os estilemas conceituais, cuja longa vigência na tradição filosófica dificultou, ao fim e ao cabo, que a reflexão sobre arte e política escapasse à ação normativa (que se revela na posição tutorial do filósofo quanto à ação do receptor e, muitas vezes, também na compreensão que ele faz do objeto "arte"). Pretendemos que o contraste entre o rigor destes estilemas, e a flexibilização que eles recebem em Deleuze e Guattari, sugira a obra destes últimos como uma via para a reversão do quadro normativo.
\end{abstract}

Palavras-Chave Recepção; Crítica de Arte; Aísthesis * Doutorando em Filosofia pela Universidade Federal de Minas Gerais. Artigo recebido em
15/09/05 e aprovado em 15/11/05.

KRITERION, Belo Horizonte, $\mathbf{n}^{\circ}$ 112, Dez/2005, p. 367-381 
ABSTRACT This essay focuses the relations between art and politics in their mutual autonomy, which is seen as an epistemological condition for the study of that relation. We'll analyze how the ontological particularities of art (in what refers to its production, reception, and complex interweaving of its semantic and sensorial aspects) can give rise to politically charged events, and also how those particularities can be conciliated with political criticism without being aggressed and deformed by it. We'll argue that Deleuze and Guattari's philosophy serves this purpose well; nevertheless, to make their importance clear, this essay will be almost totally dedicated to exposing the conceptual features whose long life in the philosophical tradition has made the reflection about art and politics become frequently normative (which can be seen in the tutorial position that the philosopher assumes towards the receptor of art, and also quite often in the understanding that is given to the term "art"). We expect that the contrast between the rigor of these features, and the flexibility they acquire in the works of Deleuze e Guattari will show the possibility of a way out of the normative field.

Keywords Reception; Art Criticism; Aísthesis

Este ensaio parte do pressuposto de que a ética e a política não participam a priori da ontologia da obra de arte, e de que a aproximação entre elas deve ser investigada sob a categoria da possibilidade, e não da necessidade. Ao alinharmos uma e outra, não borramos a linha que as separa, pois entendemos que a sua autonomia recíproca deve orientar o estudo das condições de possibilidade da sua convergência, que só se legitimará como hipótese à medida que souber preservar as suas diferenças ontológicas — para então compreender como a interação entre elas se dá (ou pode se dar) nos planos da ação do receptor, da imanência da obra (a sua produção, a sua carga semântica, e o seu entrelaçamento complexo entre a semântica e a sensorialidade) e das atividades crítica e judicativa. Não há como prever que, nesses três planos distintos, as palavras "arte" e "política" tenham o mesmo significado conceitual e remetam à mesma ordem de fenômenos: não há como afirmar que o produtor, o receptor e o crítico compartilhem sempre a mesma percepção e o mesmo entendimento dos fenômenos em questão; pelo contrário, isso ocorrerá apenas muito raramente. Entretanto, historicamente a associação entre a arte e a política partiu de um obscurecimento das especificidades da ação típica a cada um 
deles, o que freqüentemente obscureceu também o modo de manifestação que é próprio à arte, e que a difere das demais produções humanas.

Para esquadrinhar este território difuso, este ensaio se concentrará em um objetivo específico. Argumentaremos que alguns estilemas conceituais ("epistemológicos" é o termo de nossa preferência), de longa vigência na tradição filosófica, dificultaram que ela soubesse incorporar à reflexão sobre a arte uma autocrítica quanto à sua função tutorial no campo político, função bastante fragilizada pela "autonomização das esferas do saber" na Modernidade (lembramo-nos aqui obviamente de Weber) e pela idéia utópica de uma "comunidade de iguais" entre os cidadãos, consagrada a partir de 1789, e que vem desde então orientando a nossa episteme política. Tais estilemas são basicamente os seguintes: o entendimento do componente sensorial da arte a aísthesis - como potência de sedução e de "desvio" do receptor quanto ao "estado ideal" de atenção e mobilização ético-política postulado pela filosofia; a noção de que cada obra carrega em si uma valência política passível de ser determinada objetivamente pela inteligência filosófica - e portanto externamente à interação entre obra e receptor; por fim, a homogeneização da ação do receptor médio, que aqui chamaremos de "senso comum" sempre que ele aparecer sob um tal ângulo. Em sua somatória, tem-se com eles o "quadro normativo" de que fala o título do ensaio.

Como a digressão sobre estes temas virá a seguir, resta-nos apenas antecipar a estratégia adotada. Em primeiro lugar, não pretendemos sugerir que o quadro normativo abrange correntes, ou mesmo obras filosóficas em suas totalidades. Ele é um topos que permeia filosofias diversas e, portanto, manifesta-se em cada autor de maneiras que apenas se aproximam daquela aqui prevista (e que deve ser considerada como um "tipo ideal", mais uma vez ecoando Weber). Em segundo lugar, não pretendemos que as interpretações dos autores destacados (exceção feita, talvez, a Deleuze e Guattari) sejam "pessoais" ou "inéditas". Pelo contrário, elas repetirão, muitas vezes, visões já integradas ao domínio comum, e o nosso objetivo com elas é tão-somente o de traçar um panorama sucinto do tema que nos ocupa e dotá-lo de algum vigor historiográfico. Por fim, a filosofia de Deleuze e Guattari surgirá aqui como uma via para a reversão do quadro normativo. Acreditamos que a politização do estético recebe neles um tratamento que escapa à normatividade, em uma hipótese que então procuraremos ao menos delinear.

Se entendermos uma descrição como uma construção lógica que perfaz um simulacro do real empírico, então, em relação à recepção da literatura e da arte, uma descrição ideal seria aquela que apresentasse a oscilação entre a aísthesis (a pura resposta ao estímulo sensorial) e a atribuição de sentido 
(a semântica, a interpretação), em seus limites exatos de vigência no corpo e na mente do receptor. Pois parece que se trata de pólos imiscíveis, entre os quais limites se interpõem: é difícil imaginar o envolvimento sensual próprio à aísthesis como simultâneo à racionalização sobre o objeto que o provocou. A experiência do receptor é marcada pelo trânsito constante entre momentos de abertura sensorial e momentos de distanciamento do evento estético em que a ação da consciência ocupa a cena, ensejando daí os fenômenos da compreensão e da criticidade. Disso advém a histórica ambigüidade do pensamento filosófico quanto à potência de deslocamento própria à arte. Trata-se, é claro, de um deslocamento em relação à pragmática cotidiana, e nisso se assemelha à potência que a filosofia confere a si mesma; mas é, porém, produzido por uma força que não se dá a conhecer, que não se oferece à análise, antes se rebelando contra qualquer tentativa de apreensão. Se essa força de deslocamento pudesse ser apreendida, e então conhecida, ela poderia ser manejada pelo pensamento. Como esse não é o caso - como a sua incognoscibilidade é paralela à sua existência empírica e à sua evidência fática — - entende-se a desconfiança que dela terá o pensamento logocêntrico (que aqui não é sumariamente identificado à filosofia), que tão cedo passou a caracterizá-la — ou ao menos parte dele assim o fez —, como potência do "engano" ou do "enfraquecimento da subjetividade". Desviava-se, assim, o foco daquela força incognoscível para aquilo que se supunha ser a sua influência na sociedade e na cultura, onde seria possível apontar elementos concretos com os quais a filosofia da arte (descartado o elemento esotérico que comprometia o seu pleno exercício como produtora e tutora do saber) satisfazia a sua necessidade de remetimento ao real empírico. Uma vez construído um modelo do real que tomava como fato o que na verdade era uma especulação a respeito do efeito da arte sobre o público, tais filosofias adquiriam um verniz u-tópico que elas mesmas não reconheciam, mas que, entretanto, lhes permitia tentar controlar a aísthesis; em linhas gerais, e, mutatis mutandis, este foi o movimento empreendido por Platão (quando condena a mímesis por mentir aos cidadãos através da sedução), por Rousseau (quando condena a estetização por afastar os homens da concentração nas necessidades pragmáticas do Estado), por Schiller (quando interpreta, assim como Rousseau, a estetização como decadência da cultura), por Adorno — ao desconfiar do prazer como desguarnecimento da criticidade... A plena vigência da experiência sensorial é abafada sob uma argumentação ético-política cujo apelo a finalidades "nobres", "elevadas", ou mesmo "indispensáveis" para um certo projeto de futuro, faz submeter a arte — não sem uma dose de violência - a finalidades externas a ela, condicionando a incontrolabilidade do seu elemento catártico a uma normatividade que lhe é fenomenologicamente 
estranha: retirada do silêncio imediato do seu puro acontecer, a aísthesis passa a prestar contas à organização e à autoprodução da sociedade, para as quais os indivíduos surgem como átomos que, nesta condição, podem e devem ser teorizados com base na sua suposta homogeneidade.

Neste ensaio, da polaridade que se forma em torno da apreciação da aísthesis - ora irmã, ora inimiga do pensamento - abordaremos exclusivamente a segunda vertente. Nossa estratégia visará a análise textual, ficando despreocupada em entender os autores abordados na imanência das suas obras, e dentro do horizonte sincrônico de problemas aos quais eles respondiam. Por exemplo, em relação a Rousseau, não procuraremos inserir a sua reflexão sobre a arte na íntegra do seu pensamento, assim como tampouco discutiremos a justeza da sua crítica ao teatro francês de meados do século XVIII (cuja saturação do padrão classicista parecia de fato haver levado à banalidade). A teorização da arte que nos serve de guia — implicando a defesa da autonomia ontológica da aísthesis quanto à ética - só se tornou possível após o trabalho de Kant, mas é acima de tudo contemporânea, e o recurso à tradição filosófica servirá como estratégia para destacar a sua alteridade em relação a procedimentos epistemológicos que acreditamos ser necessário desconstruir. São, afinal, procedimentos comuns das reflexões políticas sobre a literatura e a arte aqueles que se inserem no quadro normativo. Listemos seus estilemas característicos: 1) o divórcio entre aísthesis e reflexão, analisadas individualmente em função dos seus potenciais "perigos" para a "formação política do cidadão"; 2) a conseqüente desconfiança quanto à imprevisibilidade própria ao jogo entre as duas instâncias, abafada sob a idéia de que a arte é capaz de exercer uma influência direta sobre o receptor, afetando tanto a sua consciência quanto a sua sensibilidade para as coisas do mundo, sendo portanto dotada do poder de diminuir a sua capacidade crítica e/ou a sua disposição para o "fazer pragmático" (i.e., o fazer considerado indispensável à continuidade ou ao melhoramento da sociedade); 3) o julgamento sumário do receptor, pela conseqüente desconfiança quanto à sua capacidade de posicionamento crítico diante da ameaça de "desvio"; 4) a confusão entre a descrição e a prescrição (entre a afirmação do que a arte é e do que ela deve ser), ponto em que a filosofia da arte abraça o distanciamento u-tópico freqüentemente característico — e necessário - da filosofia política, em detrimento de uma possível "ciência" da arte.

De saída, observemos que o topos filosófico segundo o qual a arte influencia o receptor unilateralmente — ou seja, a obra determina a sua própria recepção de maneira imediata, e não mediada pela disposição do receptor - é quase uma crença. Se assim o afirmamos, é porque tal postulado - em si 
questionado sistematicamente apenas a partir do trabalho pioneiro de Jauss e da Escola de Constança no final dos anos 1960 - só foi possível a partir de um outro topos subterrâneo (que aqui chamaremos de "senso comum", pela falta uma denominação legada pela própria tradição filosófica), que, apesar de não receber qualquer comprovação empírica, foi incorporado por diversas filosofias. O "senso comum” é uma categoria constituída performaticamente pelo próprio discurso, não recebendo uma abordagem individualizada, apesar de servir como base para a armadura conceitual. Pressuposto aceito a priori, ele sequer recebe um nome, pois é um fato e não um conceito, e, portanto, prescinde de uma investigação particularizada: o que decidimos denominar de "senso comum" nada mais é do que o hábito filosófico de homogeneizar a ação do receptor em seu contato com a obra de arte, não importa sob qual parâmetro valorativo (positivo ou negativo). Este é um procedimento tão corriqueiro quanto caro - diríamos indispensável — às filosofias normativas, e a naturalidade com que foi historicamente aceito impediu a investigação da possibilidade mesma de avaliação empírica do impacto da arte na formação ético-política do indivíduo e da sociedade. Tal impacto é de comprovação quase impossível, pois na formação das consciências e na influência sobre a ação política dos receptores a arte se agrega a inúmeros outros fatores indubitavelmente mais sólidos e palpáveis do que ela, cuja territorialidade grosso modo individual e idiossincrática — e portanto imprevisível — ademais dificilmente engendra a formação de um estado de consciência coletivo: "A aporia ao estudar a influência da recepção textual no comportamento do leitor, para sermos precisos, está na impossibilidade de isolar, no contexto do conhecimento relevante para motivar a ação, aquele tipo de experiência que remonta à recepção literária, e, então, avaliar sua significância para as mudanças na ação". ${ }^{1}$ No mínimo, pode-se trilhar o caminho inverso e apontar a difícil detecção da influência da arte na atuação política de cidadãos e multidões ao longo da história.

Porém o recurso ao "senso comum" é uma herança nobre. Nada parece ter impedido a consolidação da idéia de que as propriedades imanentes da obra encontrarão uma acolhida objetivável no receptor, desde cedo tratado como uma espécie de "tipo ideal”. Quando Platão diz que “(...) não devemos acreditar nem permitir que se diga que Teseu, filho de Poseidon, e Pirito, filho de Zeus, praticaram tão hediondos raptos, nem que outro qualquer filho de deus e herói tenha cometido os atos horríveis e ímpios de que são acusados", ${ }^{2}$ seu movimento 
não poderia ser mais claro: além de normativizar a produção da arte, o trecho implicitamente julga o receptor como incapaz de se afirmar contra a "debilidade ética" das obras em questão. Em sintonia com outras passagens de A República (como a quase imediatamente subseqüente, segundo a qual "Motivos estes (...) nos induzem a rejeitar semelhantes histórias, por receio de que instiguem nossos jovens a praticar com leviandade as piores ações"3), a expectativa de uma função exemplar a ser atribuída à literatura - e que Homero raramente parece honrar - vai pari passu com o veredito de mediocridade do seu público médio. Implícita está a predominância dada à semântica, não apenas pela abordagem normativa do conteúdo (que vem dotado de um alto poder de imposição mimética: "Sucede (...) que se os nossos jovens tomassem a sério tais palavras (...) dificilmente alguns deles (...) se julgariam indignos de assim proceder (...); mas, ao menor infortúnio, se abandonariam, sem a menor vergonha, a queixas e lamentações"4), mas também pela condenação da sensorialidade, ou ao menos de algumas das suas manifestações (o que imediatamente nos coloca diante de um outro procedimento-padrão do quadro normativo, a saber, a postulação de um "perigo" imanente à aísthesis, e a iniciativa de antecipá-lo para assim controlá-lo):

(...) quando um homem permite que a música o encante com o som da flauta e lhe derrame na alma, pelos ouvidos, essas harmonias suaves, moles e plangentes de que falávamos há pouco, passa a vida distraído, exultante de alegria pela beleza do canto: em primeiro lugar, suaviza o elemento irascível da sua alma, como o fogo amolece o ferro e o torna útil, de inútil e duro que era antes; mas, se continua a entregar-se ao encantamento, a sua coragem não tarda a dissolver-se e a fundir-se, até se reduzir a nada, até ser extraída, como um nervo, da sua alma, tornando-a um guerreiro sem vigor. $^{5}$

Também a condenação do teatro segue em Platão uma articulação idêntica, pois o problema não está na "mentira" do tragediógrafo, mas sim no modo de apresentação que ela recebe. Se o tragediógrafo se remetesse à ágora e argumentasse em defesa das suas idéias, então nada diferiria a sua ação do modelo de ação no "espaço público" que os filósofos da Academia pretendiam exercer - e no qual, entenda-se, se preparavam para prevalecer. Ocorre que a tragédia veiculava idéias sem apelar explicitamente ao logos, escamoteando a apresentação das idéias como tais, e assim "ludibriando" a defesa racional contra a impostura. A definição do tragediógrafo como um imitador de segunda

PLATÃO. A república, p. 83.

Ibidem, p. 78.

Ibidem, p. 106. 
ordem cumpria a função de subtrair à tragédia a sua dignidade intelectual, porém o perigo não era a mímesis em si, mas sim o seu impacto no socius: por causa dele Platão julgava necessário denunciar o desequilíbrio que a aísthesis impunha à absorção do conteúdo semântico e à disposição psíquica do público — em última análise, denunciar o próprio recurso à aísthesis como digno de desconfiança.

Apesar da distância que o separa de Platão, em Rousseau encontraremos formulações parecidas. Também o genebrino vê o estético com desconfiança, associando-o ao artifício e à decadência dos costumes: "Os romanos confessaram que a virtude militar se extinguira entre eles à medida que começaram a se conhecer em quadros, em relevos, em vasos de ourivesaria e a cultivar as belas artes (...)" ${ }^{\prime \prime}$. Ou então:

\begin{abstract}
Atualmente, quando buscas mais sutis e um gosto mais fino reduziram a princípios a arte de agradar, reina entre nossos costumes uma uniformidade desprezível e enganosa, e parece que todos os espíritos se fundiram num mesmo molde: incessantemente a polidez se impõe, o decoro ordena; incessantemente seguem-se os usos e nunca o próprio gênio. ${ }^{7}$
\end{abstract}

Daí que a pergunta premente é: "De que se trata, pois, nossa questão de luxo? Trata-se de saber o que é mais importante para os impérios — serem brilhantes e momentâneos, ou virtuosos e duráveis". ${ }^{8}$ A concentração no utilitarismo descarta o estético como corruptor, novamente pela suposta predisposição da mediania a mimetizar o estado contemplativo como regra para o comportamento cotidiano, em detrimento do "estado ativo" indispensável à saúde e ao progresso do Estado. O "Discurso sobre as ciências e as artes" não sobrevaloriza o campo semântico nem delega à arte a função de exemplo, porém mantém a condenação da experiência estética mediana através de um entendimento do homem que prevê a sua assimilação passiva da "força desviante" da aísthesis. A semântica não fornece o princípio normativo, ainda que não seja diminuído o seu divórcio com o sensorial que, ele sim, se torna objeto da legislação. Divórcio cuja necessidade parece sempre se impor, uma vez que a consideração conjunta de ambas as potências invalidaria a condenação de qualquer uma delas em separado, pois a sua coexistência - mesmo que sob a forma de uma oscilação entre pólos distintos — impediria que se determinasse a priori o efeito que teria a obra sobre o receptor individual e o público em

ROUSSEAU. Discurso sobre as ciências e as artes, p. 346.

7 Ibidem, p. 336

8 Ibidem, p. 345. 
geral, inviabilizando a normatividade (que precisa contar com a semântica e o estímulo sensorial como dados objetiváveis — e daí legisláveis —, o que não passaria de quimera a se admitir a interferência recíproca entre a aísthesis e a compreensão no processo de recepção da obra de arte). É importante deixarmos clara a absoluta atualidade da nossa reflexão, que não pode ser estendida a Platão e a Rousseau, por pressupor a autonomia da instituição artística quanto às demais esferas sociais e da experiência estética quanto à "razão" e ao "entendimento" (ambas derivadas de Kant) e, no plano propriamente político, por propor uma assimilação radical pela filosofia da arte de uma das conseqüências fundamentais da Revolução Francesa: a de ter transformado as pessoas em cidadãos - o que evoca o princípio da igualdade, até mais do que o da liberdade —, sabendo que "Ser um cidadão significava que qualquer um era aceito como uma pessoa racional, capaz de tomar decisões políticas" ["To be a citizen meant that everyone was being accepted as a rational person, capable of political decision" "]. A combinação destes pressupostos coloca em questão a legitimação da normatividade pela impossibilidade de aferimento de um ator social (ou a um conjunto de atores) do conhecimento e do poder de arbítrio sobre a realidade que a normatividade requer. A assimilação intransigente do conceito de cidadão tem ainda outra função estratégica: a de obrigar o quadro normativo a explicitar o que faz de um indivíduo um receptor politicamente preparado (o que levaria diretamente ao tema da educação, tornando-o tão inescapável para a Estética quanto ele o é para o debate político em geral) ou, então, a explicitar o abandono do ideal da "igualdade" em função de um lugar diretivo a ser ocupado pelo intelectual. No nosso entender, o desafio está em formular-se modos não-normativos para a apreciação ético-política da literatura e da arte, que saibam respeitar a sua flutuação recepcional sem se abster de exercer uma faculdade crítica que, conforme sabemos de antemão, remeterá a arte a instâncias que lhe são heterogêneas.

Esta é uma possibilidade epistemológica aberta apenas recentemente (com o termo "epistemológica" nos referimos ao aparato conceitual do qual dispomos para falar sobre um determinado assunto, mesmo que o discurso em questão não envolva a produção de conhecimento - como é freqüentemente o caso da Estética). Tomemos o exemplo da literatura, seguindo o seu decurso histórico conforme apresentado por Hans Ulrich Gumbrecht em uma série de textos seminais, ${ }^{10}$ e que neste parágrafo serão incorporados e resumidos a alguns de

9 WALLERSTEIN. World-systems analysis - an introduction, p. 51.

10 Remetemos o leitor a "A mídia literatura" (In: Modernização dos sentidos, p. 297-319); a "Patologias do sistema da literatura" (In: Corpo e forma, p. 81-114); e a "O futuro dos estudos de literatura?" (In: Corpo e forma, p. 153-175). 
seus argumentos centrais. Historicamente, Gumbrecht entende que a literatura tenha sido objeto de uma vontade intensa de teorização em razão da sua função social de produção de realidades alternativas à realidade cotidiana, combinada à indefinição do seu estatuto social (por tratar-se de um objeto cuja carência de uma necessidade auto-evidente não compromete sua produção e seu consumo). Da nossa parte, especulamos que, se a sua função residia em perspectivizar a realidade social, a legitimação de tal função demandaria a opção por um destes caminhos: 1) a arte deve a sua existência a uma disposição antropológica elementar; 2) ela é obra do gênio e então admitir-se-ia a autonomia completa da subjetividade autoral; 3) a pressuposição de uma razão completamente despragmatizada; 4) o pleno delineamento do conceito de ficção em sua distinção quanto à mentira, ao engano e ao desvario; 5) ou o somatório de todas as possibilidades anteriores. Mesmo quando o Romantismo vier a apresentar tais estilemas, do Renascimento ao Alto Modernismo, jamais haverá um acordo quanto ao que a literatura é e ao que ela deva ser — acordo do gênero que permite às instituições sociais ultrapassar suas contingências históricas e projetar a sua sobrevivência no tempo, em um modelo de análise sociológica que Gumbrecht tomou de empréstimo a Niklas Luhmann: "É como se a impossibilidade de afirmar um programa operacional para o sistema literário, programa esse capaz de assegurar normas para a produção literária e sua recepção, tivesse intensificado os esforços destinados a formular o programa [operacional] ou a unidade do conceito de 'literatura'". ${ }^{11}$ Isso também permite entender porque o sistema literário buscou em outros sistemas sociais os atributos necessários para a sua própria legitimação, entre eles os da sua suposta valência ética, moral ou política. Importante é notar que a indefinição quanto ao estatuto social do objeto levou à tentativa desenfreada de teorizá-lo com vistas a "estabilizá-lo" — ou seja, a dotá-lo de um território delineado de vigência e de influência na sociedade — , gerando uma produção teórica quase tão intensa quanto a própria produção literária. Esse fenômeno parece ter se refreado em tempos recentes, ao menos em parte, pela desconfiança de que sejamos capazes de conferir à polivocidade do tema uma formulação finalmente estabilizadora (parecemos ter finalmente abandonado a pretensão à universalidade, da qual se alimentaram tanto a poetologia quanto o quadro normativo). No caso em questão, porém, o mais importante é sabermos reconhecer e rever a imposição à literatura (e à arte) de uma função que não lhe é ontologicamente inerente, e que lhe foi conferida por razões que recentemente aprendemos a determinar, como nos mostra Gumbrecht. 
O nosso objetivo é o de preservar a observação do político, levando-o para fora do quadro normativo. Isso implica recusar 1) o julgamento a priori do "senso comum"; 2) a prática judicativa que pretende decretar a valência política — seja ela "nociva" ou "positiva" — da obra de arte em sua imanência ("imanência" aqui significa: em seu isolamento quanto à sua própria recepção); 3) e a dotação da arte de qualquer potência ou status político a priori: apenas no seu acontecimento pode a arte politizar-se dentro de uma relação particular com um receptor individual (e apenas ocasionalmente com o público em larga escala). Schiller - para quem o gosto "perfeito" superaria tanto a espontaneidade bruta do populacho quanto a artificialidade dos hábitos "civilizados" - é aqui uma referência negativa. A sua conceitualização do "estado estético" é na verdade uma utopia sobre o que seria o impacto de uma aísthesis proporcionada pelo belo sobre um receptor-cidadão adequadamente educado para a sua experiência (pois o belo em si nada garante, e há que se precaver contra a incapacidade da sua "boa fruição" através de uma "educação para o belo" a começar na idade mais tenra). A expectativa é a de que tal experiência seria despragmatizada apenas na medida exata a proporcionar um retorno pragmático à realidade, enriquecido por um momento de distanciamento que, conquanto despragmatizado, não fora desviante. Vê-se assim que o quadro normativo soube acolher a especificidade da aísthesis, dando-lhe todavia uma função de distanciamento. Que essa definição funcionaliza a experiência estética, isso se vê pela constatação óbvia de que um "distanciamento" se dá em relação a algo, ou seja, a alguma instância que o filósofo determina como prioritária. Este ato de determinar uma hierarquia de valores é o gesto normativo por excelência e, se poderíamos dar a Schiller a licença de pertencer a uma época ainda eufórica quanto ao poder diretivo da razão - e, por extensão, da posição de autoridade do intelectual —, a pretensão à universalidade (implícita na suprematização da política como termo de referência para a reflexão sobre a arte) há muito não se justifica. Tanto pelo autoritarismo do arbítrio, quanto pela precariedade da comprovação factual da influência da arte na formação ético-política do homem e dos processos sociais de larga escala, é insustentável conferir universalidade à ética e à política como parâmetros judicativos da arte.

Até aqui, procuramos mostrar que essa inadequação se deve não apenas aos motivos aos quais acabamos de nos referir, mas também à inevitabilidade da imposição de um controle sobre ao menos um dos eixos da experiência estética: a aísthesis e a semântica. A pelo menos uma delas será imposto um "dever ser" que, como tal, só pode ser estranho à poiesis - da produção e da recepção - própria à arte. No limite, o controle prevê que a obra tenha o 
poder de determinar a sua própria recepção, o que permite ao quadro normativo estender-se tanto à ação — supostamente passiva — do receptor, quanto à obra em sua imanência. Superar esse quadro impõe então escapar de ambas as aporias. Impõe não apenas compreender a relação entre obra e receptor como uma interação dinâmica, mas também entender que a sua participação na constituição da valência política de cada indivíduo se dá em uma interação dinâmica com uma pletora incontrolável de elementos. Cumpre ademais entender que a experiência estética tensiona a semântica e prescinde da atenção característica da ação consciente (pelo contrário, uma alta dose de desatenção lhe é inerente, na medida em que estar "alerta" é apenas um dos estados mentais possíveis no decurso do evento). Aqui, mesmo a noção de "comunicação" que se poderia cogitar adequada - revela-se problemática, pois a princípio não existe a bipartição entre um "pólo emissor" e um "pólo receptor": o receptor está lançado em um processo de interação que se inicia na co-presença da obra, nascendo daquele encontro, e não de algo - de uma possível intenção de comunicação da obra - que o precedesse. Naquilo que nos interessa, a tensão final reside em que, mesmo se subtraindo à racionalidade, a experiência estética nem por isso a afeta menos - e a política, dentro da contingência desta dinâmica, existe como possibilidade, e prescinde do filtro da razão; ela é, acima de tudo, um fato não-hermenêutico.

A filosofia que oferece a fundamentação epistemológica desta teorização é a de Gilles Deleuze, em especial na sua parceria com Félix Guattari. Não restam dúvidas quanto à vocação não-hermenêutica desta filosofia - ou melhor: anti-hermenêutica - , nem quanto ao seu teor político. Como tampouco pode-se duvidar da centralidade que a arte nela ocupa, devemos compreender a maneira como os três elementos se combinam.

Tomaremos a distinção proposta por Ivan Domingues entre "paradigmas" e "modelos". ${ }^{12}$ Grosso modo, os primeiros referem-se a teorias que pautam a relação das proposições científicas com os seus objetos de estudo, e os últimos, às metodologias utilizadas para o seu estudo efetivo. Os paradigmas se subdividiriam em três modalidade interconectadas: o paradigma-teoria (estilema teórico predominante e determinante em cada paradigma), o paradigma-objeto (o objeto de estudo preferencial de cada paradigma) e o paradigma-disciplina (a disciplina a que cada teoria confere proeminência ou com a qual estabelece, por assim dizer, uma relação de "afinidade eletiva"). Sabemos que Domingues trabalha estas categorias tendo em mente a epistemologia das ciências humanas,

12 C.f. DOMINGUES. Epistemologia das ciências humanas - Tomo 1: Positivismo e Hermenêutica (Durkheim e Weber), p. 49-83. 
e não da filosofia. Confiamos porém na validade da aproximação, sugerindo que, em Deleuze e Guattari, o paradigma-teoria é a contingência, o paradigmaobjeto é o movimento, a diferença, ou a modificação, e o paradigma-disciplina é a arte. O modelo elaborado e empregado por eles seria o rizoma, na verdade o conceito que, a partir de 1976, orientou as suas análises dos temas abordados.

A importância desta "limpeza de terreno" epistemológica está em que ela nos ajuda a compreender como pôde aquela filosofia preservar o potencial político da arte sem restringi-la ao campo semântico, e sem tampouco fazer da aísthesis um evento radicalmente alheio à razão. Em Deleuze e Guattari a arte tem o poder de desterritorialização, de colocar em movimento o que era estático (desterritorializar é impedir o sedentarismo, a segurança do território familiar; ou seja, é desviar da rotina). Este movimento é político por si só, pois para os dois autores o politicum efetivo reside na alteração da relação com o dado, que é em si uma alteração do próprio dado, seja ele de qual ordem for: "Em Deleuze, a idéia de potência implica a de diferenciação imanente, já que toda potência, realizando-se em graus, corresponde a aumentos de diminuições ou diferenças no desenvolver-se daquilo que está em pauta". ${ }^{13}$ As pessoas e as coisas estão em uma relação de contato constante, na qual a formação de um estado passível de ser caracterizado como tal - do tipo "estado $=x$ ", $x=y$ - ou bem é fruto de uma vontade de dominação e controle (o gesto hermenêutico-edipiano por excelência ${ }^{14}$ ), ou bem é o estar sufocado pelo senso comum a ponto de perder de vista a possibilidade da diferença, ou mesmo a possibilidade — e a lida — da simples ignorância (que correspondem à hermenêutica do "senso comum"). A arte desterritorializa ao bloquear a continuidade do fluxo; ela é o paradigmadisciplina em Deleuze e Guattari por emblematizar a dimensão poiética própria à interação das pessoas e das coisas dentro da realidade. O empírico é o campo em que os encontros se dão, dominado pela semantização — pela atribuição de significado às coisas -, e pela correlata estabilização do sentido ("um homem é um homem e uma mulher é uma mulher", ou então com a resposta a perguntas tais como "para que isto serve?"). Diante de um delineamento tão negativo do empírico, a vida só acontece mediante o escape da repetição e o acontecimento da diferença. O elemento poiético da metafísica deleuziana é o agenciamento, um movimento a-subjetivo que, ao permitir um instante de quebra da continuidade, provoca a irrupção da diferença, e que tem na arte (mas não só nela, como veremos na citação a seguir) um "correlato objetivo":

13 ALMEIDA. Estudos deleuzeanos da linguagem, p. 28.

14 Como se vê, por exemplo, na frase: "Mas que enorme arcaísmo textual é esse, o significante, que submete a literatura à marca da castração e santifica os dois aspectos da sua forma edipiana?" (DELEUZE e GUATTARI, O anti-Édipo, p. 140). 
(...) dizemos (...) que a arte e a ciência têm uma potencialidade revolucionária e nada mais, e que essa potencialidade aparece tanto mais quanto menos querem saber o que elas querem dizer do ponto de vista dos significados ou de um significante que estão forçosamente reservados aos especialistas; mas que eles fazem passar no socius fluxos cada vez mais descodificados e desterritorializados, em que toda a gente repara, que obrigam a axiomática social a complicar-se cada vez mais, a saturar-se ainda mais, a tal ponto que o artista e o sábio podem ser determinados a juntarem-se a uma situação objetiva revolucionária como reação às planificações autoritárias de um Estado incompetente por essência, mas sobretudo castrador. ${ }^{15}$

O tom de manifesto não esconde os elementos que nos interessam diretamente. Vemos que toda diferença é imediatamente política, pois escapa à estabilização do significado, antes referindo-se à potência a-racional do desejo. O desejo é que entra em ação ao se ver colocado diante da pura facticidade da arte e da ciência (do seu puro colocar-se à mostra). Este impacto ignora qualquer direcionamento externo, dando origem a movimentos imprevisíveis e incognoscíveis para os próprios indivíduos e para a própria sociedade em questão, até mesmo durante o processo do seu acontecimento — pois é radical o seu caráter a-semântico. Para Deleuze e Guattari, semantizar o acontecimento é devolvê-lo às garras do Estado, uma vez que mesmo um conteúdo revolucionário pode ser assimilado pelo pensamento estabelecido. O que escapa ao filtro do pensamento, seja qual for a sua índole política, é o desejo. O pensamento é controlável; o desejo, não:

O desejo não "quer" a revolução, ele é revolucionário por si mesmo, e como que involuntariamente, só por querer aquilo que quer. Defendemos desde o começo (...) a identidade de natureza da produção social e da produção desejante e a sua diferença de regimes, de modo que a forma social de produção exerce uma repressão essencial sobre a produção desejante, e a produção desejante (um "verdadeiro" desejo) pode potencialmente fazer a forma social ir pelos ares. ${ }^{16}$

A contingência, então, é absoluta (e aqui chegamos finalmente àquele que consideramos ser o paradigma-teoria de Deleuze e Guattari). Vale lembrar o quanto Deleuze insiste na possibilidade de que uma obra de arte revolucionária provoque um agenciamento fascista: a rigor, não existe previsão possível quanto ao impacto político que uma obra terá sobre o público, assim como tampouco existem indivíduos completamente desprovidos de linhas de estratificação politicamente daninhas. Não existe obra ou indivíduo revolucionário, existe apenas o acontecimento revolucionário, que só pode ser obra da contingência. 
O rizoma decerto forma "arborescências" ou "tubérculos", mas não há de antemão como saber de que tipo eles serão e, mesmo que eles venham a ser politicamente "positivos", não haverá como saber por quanto tempo durará tal positividade - que se estratificará em uma rotina, que exigirá, por sua vez, um novo acontecimento revolucionário, e assim por diante.

Em Deleuze e Guattari a reflexão política sobre a arte foge ao quadro normativo. À crítica estético-política caberá um novo papel, que jamais será, novamente, de cunho tutorial, e que deverá reinventar a sua relação com a empiria - em um desenho que nos cabe agora começar a imaginar. Sabemos que esta tarefa não poderá ser em vão, uma vez que, se nos é vedado determinar o politicum fora da relação, o fato é que a relação clama - e continuará a clamar - pelo político, que não está nas coisas, mas que vem a nós em nossa relação com as coisas, exigindo um posicionamento — um "movimento" que é, em si, a ética em seu acontecer espontâneo.

\section{Referências}

ALMEIDA, Júlia. Estudos deleuzeanos da linguagem. Campinas: Editora Unicamp, 2003.

ARISTÓTELES. Poética. São Paulo: Ars Poetica, 1993.

DELEUZE, Gilles; GUATTARI, Félix. $O$ anti-Édipo - capitalismo e esquizofrenia. Lisboa: Assírio \& Alvim, [s.d.]. (edição original em francês: 1972).

. Mil platôs: capitalismo e esquizofrenia. São Paulo: 34, 1995-1997. 5 v.

DOMINGUES, Ivan. Epistemologia das ciências humanas — Tomo 1: Positivismo e Hermenêutica (Durkheim e Weber). São Paulo: Edições Loyola, 2004.

GUMBRECHT, Hans Ulrich. Modernização dos sentidos. São Paulo: 34, 1998. Corpo e forma. Rio de Janeiro: EdUERJ, 1998.

PLATÃO. A república. São Paulo: Nova Cultural, 2000.

ROUSSEAU, Jean-Jacques. Discurso sobre as ciências e as artes. São Paulo: Abril Cultural, 1978. (Col. Os pensadores).

WALLERSTEIN, Immanuel. World-systems analysis — an introduction. Durham: Duke University Press, 2004. 